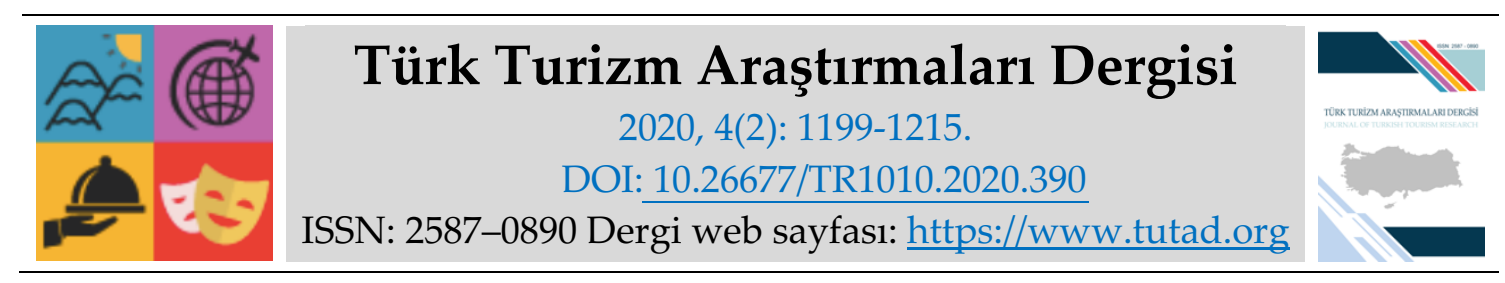

ARASTIRMA MAKALESI

\title{
Şikâyetin Ödüldür Bize: Etkinlik Bilet Dağıtımı ve Biletix Şikâyetleri
}

Prof. Dr. Mehpare Tokay ARGAN, Bilecik Şeyh Edebali Üniversitesi, Uygulamalı Bilimler Fakültesi, Bilecik, e-posta: mehpare.argan@bilecik.edu.tr ORCID: https://orcid.org/0000-0002-8996-082X

Arş. Gör. Mehmet Tahir DURSUN, Anadolu Üniversitesi, Sosyal Bilimler Enstitüsü, Eskişehir, eposta: mehmettahirdursun@anadolu.edu.tr

ORCID: https://orcid.org/0000-0002-9390-3529

Öz

Günümüz teknolojisinin ortaya koyduğu ve iş yapış biçimlerini yeniden şekillendirdiği alanlardan biri online dağıtım kanallarıdır. Online dağıtım, somut ve sanal ürünlerin dağıtımında etkin olarak kullanılmaktadır. Bu anlamda online dağıtıma uygun ürünlerden biri de rekreasyon etkinlikleri için internet üzerinden satılan etkinlik biletleridir. Etkinlik organizasyonları ve etkinlik katılımcısı arasında aracı konumunda yer alan Biletix, farklı etkinlikler ile ilgili hedef kitleyi haberdar etmek ve etkinlik katılımı için gerekli olan bilet satışını gerçekleştirmektedir. Bu çalışmada, biletix.com sitesinden hizmet alanların şikâyet davranışları ve konularını tespit ederek, biletix.com için şikâyet yönetim sürecine önerilerle katkı sağlamak amaçlanmıştır. Veriler, 2017 Ocak -2018 Mart ayı içerisinde şikayetvar.com sitesinde Biletix başlığı altında bulunan şikâyetlerden oluşmaktadır. Şikayetlerin analizi sonucunda; hizmet, fiyat, web sitesi, müşteri hizmetleri, mekân, bilgilendirme, dağıtım ve promosyon-tanıtım ana temaları ortaya çıkmıştır.

Anahtar Kelimeler: E-Şikâyet, Biletix.Com, Rekreasyonel Etkinlikler.

Makale Gönderme Tarihi: 27.09.2019

Makale Kabul Tarihi: 03.04.2020

\section{Önerilen Atıf:}

Argan, M. T. ve Dursun, M. T. (2020). Şikâyetin Ödüldür Bize: Etkinlik Bilet Dağıtımı ve Biletix Şikâyetleri, Türk Turizm Araştırmaları Dergisi, 4(2): 1199-1215.

(C) 2020 Türk Turizm Araştırmaları Dergisi. 


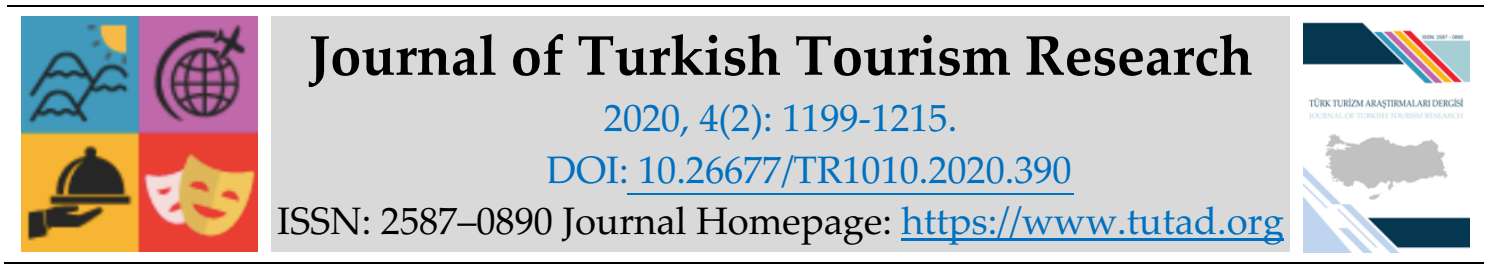

\title{
$\underline{\text { RESEARCH PAPER }}$
}

\section{Complain with You Reward Me: Event Ticket Delivery and Biletix Complaints}

Prof. Dr. Mehpare Tokay ARGAN, Bilecik Şeyh Edebali University, Faculty of Applied Sciences, Bilecik, e-mail: mehpare.argan@bilecik.edu.tr ORCID: https://orcid.org/0000-0002-8996-082X

Research Assistant Mehmet Tahir DURSUN, Anadolu University, Institute of Social Sciences, Eskişehir, e-mail: mehmettahirdursun@anadolu.edu.tr ORCID: https://orcid.org/0000-0002-9390-3529

\begin{abstract}
One of the areas that today's technology reveals and reshapes the way of doing business is online distribution channels. Online distribution is effectively used in the distribution of concrete and virtual products. In this sense, one of the products suitable for online distribution is the event tickets made for recreation activities over the internet. Biletix, which acts as an intermediary between the event organizations and the event participant, realizes the sale of the tickets necessary for informing the target audience about the different events and participating in the event. In this research, it is aimed to determine the complaints behavior and complaints of the users of Biletix.com and to contribute to the complaint management process for Biletix. The data consists of complaints under Biletix on January 2017-March 2018 on the website of Sikayetvar.com. The content analysis method was used to evaluate the complaints. As a result of the analysis is that complaints; service, price, website, customer service, space, information, distribution and promotion-promotion are the main themes.
\end{abstract}

Keywords: E-Complaint, Biletix.Com, Recreational Activities.

Received: 27.09.2019

Accepted: 03.04.2020

Suggested Citation:

Argan, M. T. and Dursun, M. T. (2020). Complain with You Reward Me: Event Ticket Delivery and Biletix Complaints, Journal of Turkish Tourism Research, 4(2): 1199-1215.

(C) 2020 Türk Turizm Araştırmaları Dergisi. 


\section{GİRIŞ}

Teknoloji ile internet günümüz toplumunda ve endüstrilerde önemli gelişmelere fırsat sunmaktadır. Şirketler, ülkeler, destinasyonlar başarılı bir marka olarak tanınmak için sosyal medya, internet ve online tanıtım modellerini en iyi şekilde kullanma çabasına girmektedir (Sarı ve Kozak, 2005:250). İnternetin insan toplumuna derin bir şekilde temas etmesi yaşanılan sevinç, üzüntü, keder, özlem, arzu, dilek ve şikâyet gibi duyguları online ortamlarda paylaşma ihtiyacını doğurmaktadır. Bu durum tüketim davranışını da oldukça önemli bir düzeyde etkilemektedir. Geleneksel mecralarda ve online sitelerde alışveriş yapan tüketiciler olumlu ve olumsuz deneyimlerini online ortamlarda paylaşmaktadır. Bu paylaşımlar hem tüketicilerden potansiyel tüketicilere uyarı hem de kendi yaşadıkları sorunlara çözüm bulmak için dile getirdikleri şikâyetleri içermektedir. Bu bağlamda, şikâyet yönetimi, tüm işletmeler için önemli bir müşteri ilişkileri unsurudur. Nitekim, şikayetlerin çözüme kavuşturulması mevcut müşterilerin sadakatine ve potansiyel müşterilerin de dikkatini çekmeye yönelik başarılı sonuç veren yöntemlerden biridir (Aymankuy, 2011:226).

Tüketiciler satın alımdan sonra ürüne ilişkin yaşadıkları memnuniyetsizlikleri ya işletmelerin müşteri hizmetleri birimine ya da internet ortamında işletme ve tüketicileri bir araya getiren çevrimiçi web sitelerine yorumlar atarak paylaşmaktadır (Şahin ve Alkaya, 2017:89). Bu çalışma, rekreasyonel aktivitelere katılım için gerekli olan etkinlik biletlerinin dağıtımını yapan Biletix web sitesinde online bilet alan tüketicilerin bilet satın alma ve sonrası deneyimlerine ilişkin şikayetleri temel almıştır. Bu amaçla şikayetvar.com sitesinde Biletix başlığı altında yer alan şikâyetler incelenmiştir. Araştırma sonucunda biletix.com ve diğer online dağıtım kanalları için şikâyet yönetim sürecinde nelere dikkat edilmesi gerektiği ortaya konarak, hizmet politikalarını geliştirmeleri için birtakım önerilerde bulunmak hedeflenmektedir. Ayrıca, bilimsel alanda yapılacak çalışmalara katkı sağlaması da beklenmektedir.

\section{ETKİNLIKLERDE BİLET DAĞITIMI}

Etkinlik yönetimi için katılımcıların varlığı ve buna bağlı olarak bilet dağıtımı etkinliğin başarısını doğrudan etkileyen stratejik bir faaliyettir. Etkinliklerde biletleme, etkinlik mekânının en iyi şekilde yönetilmesi için kritik bir öneme sahiptir. Biletleme, etkinliklerde kalabalık yönetimi, nakit akışının sağlanması ve etkinlik imajının yaratılmasında bir strateji olarak kullanılmaktadır. Biletlemenin ve bilet satış sistemlerinin bir diğer avantajı ise müşteriler ile doğrudan iletişimin ve ilişkinin kurulması ve müşterilerin etkinliklere katılım davranışlarına ilişkin verilerin toplanmasıdır (Tokay Argan ve Yüncü, 2016).

Etkinliklerde bilet dağıtımında biletlerin son müşterilere "satışı" ile ortaya çıkan birincil bilet pazarı ile biletlerin "el değiştirmesi" sonucu ortaya çıkan ikincil bilet pazarı bulunmaktadır. İkincil bilet pazarı birincil bilet pazarında satılan biletlerin "tekrar satışı" olarak tanımlanmaktadır. İkincil bilet pazarında aracılar etkinlik biletlerini etkinlik organizatörü ya da birincil satıcıdan satın almakta ve satış yeteneğine bağlı olarak bilet fiyatına belirli bir kar oranı ekleyerek satış yapmaktadır (Bhave ve Budish, 2017:3). Bu durumda işveren-acenta sözleşmesinden farklı olarak, ikincil pazarda yer alan aracılar tekrar satış fiyatını belirlemekte, özgürce hareket edebilmekte, ancak satılamayan bilet riskini de üstlenmektedirler. Viagogo Seatwave Get Me In! ve eBay ikincil bilet pazarında faaliyet gösteren en büyük internet platformları olarak gösterilmektedir (Europe-economics, 2009).

$\mathrm{Bu}$ çalışmanın temel konusunu birincil bilet pazarları oluşturmaktadır. Birincil bilet pazarı; bir etkinliğin biletlerinin doğrudan satışı ya da etkinlik organizatörünün namına biletlerin dağıtımı ve satışı olarak tanımlanmaktadır. Etkinlik biletlerinin müşterilere ulaştırılmasında bilet gişeleri, çağrı merkezleri, bilet acentaları, internet platformları, mekân organizatörleri ve medya gibi 
çeşitli aracılar yer almaktadır (Tokay Argan ve Yüncü, 2016). Etkinlik bilet dağıtımında; hız, kolaylık, güvenlik, güncel teknoloji açısından en avantajlı kanallardan biri internet platformlarıdır (Bowdin vd., 2006; Tokay Argan ve Yüncü, 2016). İnternet ortamında dağıtım, teknoloji tabanlı olarak hızlı ve sürekli gelişmektedir. Bu yüzden internet, potansiyel ve mevcut tüketicilere ulaşma konusundaki kullanışlılığı sayesinde birçok sektörde tercih edilen dinamik bir dağıtım kanalı olarak görülmektedir (Yıldırım, 2015:12). İnternet platformları spor, kültürel ve iş amaçlı etkinlikler gibi farklı kategorideki etkinliklerin biletlerinin satışında uzmanlaşmış büyük ölçekli işletmelerdir. Etkinlik organizatörleri dışında birincil bilet pazarı aracıları Ticketmaster, Ticketline, Tickets.com, Seetickets, Lastminute.com ve Ticket web'tir. Bunlar arasında en fazla bilet satışı gerçekleştiren ise TicketMaster internet platformudur.

Etkinlik biletlerin dağıtımında bir aracı kullanmanın faydaları etkinliğin türüne, diğer bilet dağıtım alternatiflerinin (bilet gişesi ya da doğrudan e-posta gibi) ulaşılabilirliğine, bir biletleme hizmeti için hedef pazarın ödeme yapma isteğine bağlıdır (Bowdin vd., 2006). Bu avantajlara karşılık etkinlik organizatörü açısından bilet satışı için aracıların kullanılmasının dezavantajları da bulunmaktadır (Beaven ve Laws, 2004: 184). Bu dezavantajlar ise etkinliğin ekonomik etkisini azaltacak doğrudan maliyetlere katlanma, acentaya ödenecek komisyonlar nedeniyle müşterilerin katlanacağ maliyetlerde artış, müşteriye sunulan hizmetlerde kontrol sahibi ve talebin özellikleri hakkında tam bilgi sahibi olmamak, müşterilere ilişkin elde edilebilecek bilgilerden yoksun kalmak ve bu nedenle ilişkisel pazarlama eylemleri geliştirilirken büyük zorluklarla karşılaşmak ve kriz durumlarında daha yavaş reaksiyon vermek sayılabilir. Bu bağlamda etkinlik organizatörleri etkinlik biletini aracı kullanarak dağıtması durumunda ortaya çıkacak müşteri şikâyetlerinde ortak sorumluluk taşımaktadır. Bunun yanında etkinliklerin sahnelenmesi, iptal edilmesi ya da mekân ile ilgili müşteri şikâyetleri konusunda da bilet satış işletmesi sorumlu tutulabilecektir.

\section{TicketMaster İnternet Platformu ve Biletix}

Etkinlik bilet satışlarının birincil pazarlarının en önemli aktörleri etkinlik organizatörleri ve bilet acentalarıdır. $\mathrm{Bu}$ işletmeler birincil bilet pazarındaki satışlardan sorumludurlar. Etkinlik organizatörü ve bilet acentası arasındaki temel farklılık: etkinlik organizatörü bilet fiyatlama stratejilerinin belirlenmesinden sorumlu iken; bilet acentası ise belirli bir komisyon karşılığında etkinlik organizatörü adına kendi satış noktalarında biletlerin satışından sorumludur (Europeeconomics, 2009). Genel olarak endüstride etkinlik organizatörü ve birincil bilet satışından sorumlu satıcılar biletlerinin aracılar ile dağıtımında iki yol izlemektedirler. Birinci durumda, bilet acentasının görevi, etkinlik organizasyonu adına biletlerin dağıtımını sağlamakta ve satılan bilet sayısı veya bilet değerine bağlı olarak belirli bir miktar komisyon ücreti almaktadır. Sözleşmeye dayalı bu ilişki türü "düzenlenmiş işveren-acenta sözleşmesi" olarak tanımlanmaktadır.

1976'da kurulan Ticketmaster, farklı kıtalardan 21 ülkede Live Nation Entertainment çatısı altında hizmet veren dünyanın en büyük bilet acentasıdır. İşletme etkinlik biletlerinin perakende satıcılar/satış noktaları, telefon ya da güvenli bir internet sitesi aracılığı ile dağıtımını ve satışını gerçekleştirmektedir. Ticketmaster, müşteri ile etkinliğin buluşmasını sağlamak için biletlerin dağıtımında, gerçek bilet değerine bir hizmet ücreti (komisyon) eklemektedir (Jennings ve Happel, 2002). İşletme 2012 yılında müzeler, kültürel kurumlar, spor ligleri ve takımları, etkinlik organizatörleri ve etkinlik mekânlarından oluşan müşterileri adına 148 milyon etkinlik bileti satarak 10 milyar dolar ve 2013 yılında ise yaklaşık 400 milyon biletin yönetimi ve satışını gerçekleştirmiş ve 17 milyar dolar hasılat elde etmiştir. Dünya genelinde popüler olan TicketMaster'ın Avrupa'da pazarın yaklaşık \%50'sine hâkim olduğu belirtilmektedir. Ticketmaster Türkiye'de Biletix.com sitesi aracılığıyla bilet satışını gerçekleştirmektedir. 
Biletix.com, 1 milyondan fazla kayıtlı kullanıcısına yılda ortalama 600 organizatörün 13000'den fazla etkinliği için yaklaşık 3,5 milyon bilet satışı yapmaktadır (www.biletix.com). Biletix müşterilerinden hizmet bedeline ek olarak, biletleme ücreti, online giriş kartı ve oturum düzenine göre farklılaşan bir fiyatlama politikası uygulamaktadır. Ayrıca Biletix sadece online bilet satışı gerçekleştirmemekte; web sitesinde belirtilen satış gişelerinden de perakende satışı gerçekleştirmektedir. Bu kapsamda online web sitesi dışında Türkiye'nin farklı illerinde bulunan otuz perakende satış noktası bulunmaktadır.

Müşteri sadakatini elde etmek amacıyla işletmeler bir takım sadakat programları geliştirmektedir. Sadakat programlarının en çok kullanılan yöntemi işletmelerin düzenli kullanıcılarına sunduğu üyelik kartlarıdır (Erk, 2009:75). Bu kartlar aracılığıyla hem müşterilerin bireysel verilerine ulaşma hem de elde edilen bilgilerle müşteri ilişkilerini başarılı bir şekilde yönetme fırsatı ortaya çıkmaktadır (Kulabaş ve Sezgin, 2003:80). Biletix.com da üyeleri için sadakat programları geliştirmiş ve Kültür Sanat Kart ile Lale Kart gibi iki uygulama yürütmektedir. Bu kartlar sayesinde etkinlik tüketicileri farklı etkinliklerde \%20-30 arasında indirimli bilet almaktadır. Siyah, beyaz, mavi renklerindeki lale kart sahibi olan müşteriler düzenlenen etkinliklerde yer garantisi, açılış günlerine özel günlere katılım sağlama ve etkinlik alanlarında otopark ve vale hizmetlerinden ücretsiz yararlanabilmektedir. Ek olarak hediye kart uygulaması ile müşterilerin diğer potansiyel tüketiciler için hazırladığı bir yıllık ücretsiz etkinlik katılım imkânı sunmaktadır. Aylık dergi de çıaran Biletix, her ay periyodik olarak etkinliklerin tanıtımını, yeri ve zamanını paylaştıkları bir platform sunmaktadır. Etkinlikleri bu dergide, müzik, sahne, festival, youtube, aile, spor ve eğitim şeklinde gruplandırmaktadır. Ayrıca, dünya geneli organizatörlerin düzenlediği etkinlikler dışında sosyal sorumluluk projesi kapsamında kanser araştırmaları vakfına bağışlanmak üzere kermes, eğlenceli koşu ve oyun geceleri gibi etkinlikler düzenlemekle birlikte tüm yıl boyunca yapılan etkinliklerde bilet satış işlemi sırasında "bağı̧s yap" seçeneği ile kanserle mücadele için maddi destek toplamaktadır (www.biletix.com).

\section{Online Bilet Satışında E-şikâyet}

Bilet dağıtım kanalları, etkinlik organizatörlerinin ürettikleri mal ve hizmetleri ulaştırma konusunda fayda sağlayan kolay ve hızlı bir yöntem olarak kabul edilmektedir (Eroğlu vd., 2008:98; Buhalis, 1998:414). Katılımcılar, etkinlik organizasyonunun belirlediği satış noktalarından ya da online web sitesinden etkinlik biletlerini satın almaktadır. Biletix.com ise bilet dağıtım kanalı olarak birincil bilet pazarında baskın rol oynayan ve etkinlik biletlerini tüketicilerle buluşturan bir dağıtım kanalıdır. Etkinlik katılımcıları, etkinlik biletini satın alma esnasında, satın alma sonrasında ve etkinliğe katılımda biletix ve etkinlik organizasyonuna yönelik hizmet hataları ile karşılaşmakta ve bu hatalara çözüm üretilmesi içinde farklı şikâyet kanalları kullanmaktadır. Bu şikâyetlerin doğru kanallar aracılı̆̆ıyla doğru işletmeye ulaşması önem taşımaktadır. Bu bağlamda müşteri şikâyeti, satın alınan mal ve hizmet sonrasında bireylerin işletmelere veya üçüncü şahıslara resmi olarak memnuniyetsizliklerini ifade etmesi şeklinde tanımlanmaktadır (Singh ve Widing, 1991:32; Lovelock ve Wright, 1999; Bell vd., 2004:113). Şikâyetlerin iletilmesi işletmeler için hem hizmetlerin iyileştirilmesi için bir fırsat hem de tüketici sadakatini sağlamak için bir kazanım sağlamaktadır. Ancak, şikâyetlerin tatminkâr bir çözüm sağlayacak şekilde çözümlenmediğinde; tüketicinin tekrar satın almaması ve yaşadığı olumsuz deneyimi başka tüketicilere aktarması gibi olumsuz sonuçlar doğurmaktadır (Pei-Wu ve Ya-qui, 2006: 958; Barış, 2008). Bu durumların ortadan kaldırılması için işletmelerin bir şikâyet yönetim sürecini işlevsel hale getirmeleri gerekmektedir. Şikâyet yönetim süreci, tüketicilerin deneyimleri esnasında karşılaştıkları memnuniyetsizliklerinin ortadan kaldırılması, hizmet hatalarının tespit edilerek çözülmesi ve potansiyel sorunların engellenmesi için yapılan tüm faaliyetleri kapsamaktadır (Vos ve Huitema, 2008: 12, Gökdeniz vd., 2011: 176). 
Günümüz teknolojisi geleneksel şikâyet kanallarına ilave olarak daha etkin, hılı ve geri dönüşümü yüksek bir ortam sağlamıştır. Online ortamda bulunulan şikâyet ile e-şikâyet kavramı ortaya çıkmıştır. Tüketiciler tarafından e-şikayetler işletmenin web sayfasına, şikâyet sitelerine ve yasal kurumlara online olarak iletilebilmektedir. E-şikâyet siteleri ve paylaşım forumları ise, tüketiciler için rahatsızlıklarını hızlı bir şekilde işletmelere iletebildikleri, internet ortamlarıdır (Aylan vd., 2016:57). Bu sitelerde yapılan paylaşımlar aynı zamanda diğer kullanıcılara işletme hakkında bilgi sağlayarak potansiyel tüketicilere bir karar süreci hazırlamaktadır. Böylece diğer tüketiciler olumlu ve olumsuz deneyimleri değerlendirerek işletmelerin hizmet politikaları hakkında bilgi sahibi olmaktadır (Alrawadieh ve Demirkol, 2015:132; Ünver, 2010:55).

Tüketicilerin şikâyetlerini işletmeye iletmeleri sonrasındaki çözümlere yönelik de bir memnuniyetsizlik durumu ortaya çıkabilmektedir (Barış, 2008). Bu yüzden, sanal dünya olarak anılan internet ortamında şikâyetlerin belirtilmesi tüketiciler açısından normal şikâyetlere göre farklı faydalar sağlamaktadır. Bunlar, hızlı telafi, diğer insanları uyarma arzusu, intikam alma ihtiyacı ve duyguları paylaşma isteği şeklinde sıralanabilir (Özkaynar, 2010: 56). Ayrıca, şikâyet yönetim süreci açısından internet ortamındaki şikâyetlerin hızla yayılarak işletme imajına olumsuz etkisi ihtimali ile doğal ortamdaki şikâyet sürecine göre daha kısa sürede çözümlenmesi mümkün olmaktadır. Tüketicilerin işletmelerin mal ve hizmetlerine yönelik şikâyetlerini internet ortamında yer alan şikâyet sitelerinde paylaşmaları kolay, hızlı ve ücretsiz bir yöntem olarak değerlendirilmektedir (Doğru vd., 2014: 34).

Literatürde, şikâyet davranışı ile ilgili çalışmalara sıkça rastlanmaktadır. Ancak, elektronik ortamda paylaşılan şikâyetler ile ilgili çalışmalar son yıllarda artış göstermektedir. Bu çalışmalar, rekreasyon, iletişim, teknoloji, turizm ve sağlıkla birlikte eğitim alanındaki şikayetlere yönelik araştırmaları içermektedir (Özkaynar 2010; Sarı vd., 2013; Cevher 2016; Tokay Argan ve Arıc1 2019). Bu bağlamda bu çalışmanın ana konusu bilet dağıtım kanalı olarak birincil pazarda faaliyet gösteren Biletix müşterilerinin bilet satın alma deneyimleri sonucu yaşadıkları problemler ile ilgili şikayetvar.com sitesinde yayınladıkları şikâyetlerin incelenmesidir.

\section{YÖNTEM}

\section{Araştırmanın Amacı ve Önemi}

Araştırmanın amacı, online alışverişlerde ortaya çıkan şikâyetlerinin incelenmesidir. Bu genel amaç doğrultusunda çalışmanın temel amacı ise etkinlik bilet dağıtımı yapan biletix.com sitesinden bilet alan bireylerin elektronik ortamda paylaştıkları şikâyetlerin analiz edilmesidir. Araştırmada, şikayetlerin neler olduğu, bu şikayetlerin ana ve alt temaların mevcut durumunu ortaya koymak, şikayetlerin yönetimi için önerilerin geliştirilmesine katkı sağlamak, online hizmetlerinin iyileştirilmesi için öneriler geliştirmek, elde edilen sonuçların gerekli kurumlar ile paylaşarak hizmet tasarımı ile belirlenen şikayetler konusunda daha duyarlı davranılmasına katkı sağlamak, online alışveriş ve online şikâyet konusunda literatüre katkı sağlamak amaçlanmiştır.

\section{Araştırmanın Yöntemi}

Biletix'in web sitesinden etkinlik katılımı için bilet satın alan tüketicilerin deneyimleri esnasında sunulan hizmetlere yönelik şikâyetlerin incelenmesi ve yorumlanması amacıyla nitel araştırma yöntemi kullanılmıştır. Çalışma verileri şikayetvar.com web sayfasında yer alan biletix.com kullanıcılarının şikâyetlerini içermektedir. Elde edilen bu şikâyetler ile metinlerin düzenlenmesi, 
sınıflandırılması, karşılaştırılması ve metinlerden teorik sonuçlar çıkarılması için doküman incelemesi yönteminden faydalanılmıştır.

\section{Örneklem}

Çalışmanın verileri, şikayetvar.com sitesinde Biletix ana başlı̆̆ı altında (Ocak 2017- Mart 2018) yapılan şikâyet metinlerinden oluşmaktadır. 422 olarak belirlenen toplam şikâyet adedi çalışma sürecinde silinen, cevaplanan ya da yayından kaldırılan şikâyetlere ulaşılamaması nedeniyle 346 şikâyet analize tabi tutulmuştur.

\section{Veri Toplama}

Araştırmada, şikayetvar.com sitesinde etkinlik bilet satışını gerçekleştiren Biletix ile ilgili şikâyetler, sikayetvar.com tarafından atanan referans kodları ile veri toplama formuna kaydedilmiştir. Bu kayıt şikâyeti yapan kişi ve şikâyetin yapıldığı il şeklinde belirlenmiştir. Sonraki aşamada şikâyetler okunarak hangi etkinlik türüne ait oldukları belirlenerek ayrı dosyalar halinde sınıflandırılmıştır. Daha sonra şikâyet etme amaçları ve şikâyetler temalandırılarak kategorize edilmiştir. Veri toplama süreci aşağıdaki akış diyagramında belirtilen aşamalarla gerçekleşmiştir.

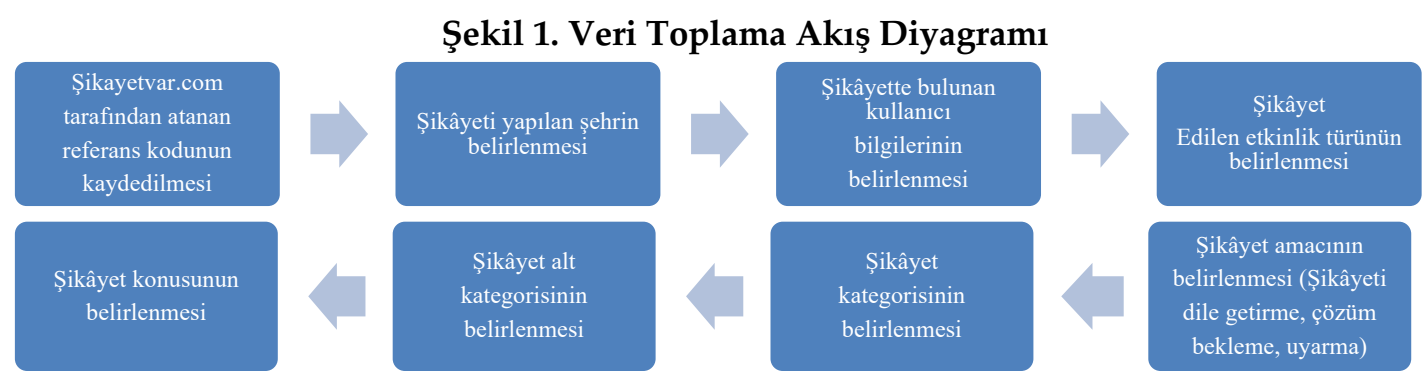

Veriler elde edildikten sonra veri akış diyagramına göre işlem yapılmıştır. Ayrıca elde edilen bulgulara ait sıklık ve yüzdeler SPSS.22 paket programına girilerek hesaplanmıştır.

\section{Kodlama Sistemi ve Analiz}

Bu aşamada şikâyet metinleri formlar üzerinde okunarak araştırma notları ile bilgisayar ortamına aktarılmıştır. Her şikâyet için kodlama yapılmış ve veriler kategorik hale getirilmiştir. Kategoriler belirlenirken şikâyet konuları dikkate alınarak kodlamalar yapılmıştır. Bu aşamada şikâyet metinleri temel alınarak kodlama türü geliştirilmiştir (Creswell, 2014). Bu kodlama neticesinde şikâyetler tek tek incelenerek temalandırılmış; temalandırma işlemi ve alt tema oluşturulma süreci başlatılmış; birden fazla ana ve alt temalara ayrılmıştır.

\section{Geçerlik ve Güvenilirlik}

Araştırmanın geçerliliğini sağlamak için e-şikâyet ile ilgili literatürün derinlemesine incelemesi yapılmıştır. Araştırmanın geçerliliğinde yoğun ve uzun dönemli ilgililik önemli bir konudur. Bu çalışma kapsamında araştırmacılar uzun dönemli şikâyet konularıyla ilgilenmiş ve kodlama sürecinde tekrar tekrar şikâyetler gözden geçirilmiştir. Çalışmanın geçerliliğini desteklemek için farklı kanıtlar elde edilmiştir. Bunun için farklı şikâyet sitelerinde Biletix ile ilgili şikâyetler gözden geçirilmiş ve benzer şikâyetlerin yer aldığı gözlemlenmiştir.

Araştırmanın güvenilirliği/inanılırlığı (trustworthiness) sağlamak için en önemli teknik olarak katılımc1 teyididir (member check) (Lincoln ve Denzin (2003). Bu nedenle Biletix'ten bilet alan kullanıcıların görüşlerine başvurulmuştur. Toplanan tüm şikâyetler analiz form dosyasına 
kaydedilmiştir. Kaydedilen şikâyetler okunarak etkinlik türlerine göre sınıflandırılmıştır. Daha sonra her şikâyet kendi içerisinde okunarak ana temalara göre sınıflandırılmıştır. Ana temalara göre ayrılan şikâyetler alt tema dosyalarına tekrar ayrılmıştır. Bu süreç iki araştırmacı tarafından ayrı olarak yapılmıştır. Sonraki aşamada kodlayıcılar arası uyum kontrolü yapılmış, anlaşmazlık durumunda tekrar mutabakat için şikâyetler tekrar gözden geçirilmiştir.

\section{BULGULAR}

Biletix ile ilgili şikâyette bulunan site kullanıcılarının ikamet ettiği illere göre dağılımına bakıldığında büyük çoğunluğunun $(\% 60,11)$ İstanbul şehrinde yaşayan bireyler olduğu tespit edilmiştir. Biletix ile ilgili şikâyetlerin hangi etkinlik türüne yönelik olduğu Tablo-1'de gösterilmektedir. Tablo-1'e bakıldığında etkinlik türlerinin ana grupları: sanatsal ve kültürel; spor, rekreasyon ve diğer etkinlikler olarak yapılmıştır. Bu ana etkinlikler ise kendi içerisinde alt etkinlik türlerine göre sınıflandırılmıştır. Sanatsal ve kültürel etkinlikler \%73,98 ile en fazla şikâyet alan etkinlik türü olmuş, onu \%10,11 rekreasyonel etkinlikler, \%8,67 ile spor etkinlikleri ve son olarak da \%7,22 ile diğer etkinlikler grubu ise en az şikâyet alan etkinlik türü olarak ortaya çlkmıştır (Tablo-1).

Tablo-1: Kullanıcıların Şikâyette Bulundukları Etkinlikler

\begin{tabular}{|c|c|c|c|}
\hline Gruplar & Etkinlik & Şikâyet sayısı & Toplam \\
\hline \multirow{7}{*}{$\begin{array}{l}\text { Sanatsal ve Kültürel } \\
\text { Etkinlikler }\end{array}$} & Konser & 150 & \multirow{7}{*}{$256(\% 73,98)$} \\
\hline & Tiyatro & 53 & \\
\hline & Gösteri & 27 & \\
\hline & Sinema & 12 & \\
\hline & Müzikal & 9 & \\
\hline & Sirk & 3 & \\
\hline & Sergi & 2 & \\
\hline \multirow{2}{*}{ Spor Etkinlikleri } & Takım Karşılaşmaları & 26 & \multirow{2}{*}{$30(\% 8,67)$} \\
\hline & Motor Yarışları & 4 & \\
\hline \multirow{3}{*}{$\begin{array}{l}\text { Rekreasyonel } \\
\text { Etkinlikler }\end{array}$} & Festival & 33 & \multirow{3}{*}{$35(\% 10,11)$} \\
\hline & Lunapark & 1 & \\
\hline & Yılbaşı Kutlamaları & 1 & \\
\hline \multicolumn{2}{|c|}{ Diğer Etkinlikler } & 25 & $25(\% 7,22)$ \\
\hline & PLAM & \multicolumn{2}{|r|}{346} \\
\hline
\end{tabular}

Kullanıcıların, belirli bir amacı gerçekleştirmek adına şikâyet etme davranışı içine girdikleri gözlenmiş, bu amaçla şikâyetler üç farklı kategoride incelenmiştir (Tablo-2). Şikâyetlerin yapılma amacına göre dağılımları incelendiğinde, şikâyetin \%33,74'ünün şikâyeti dile getirme; $\% 35,22$ 'sinin çözüm bekleme ve \%51,04'ünün diğer kullanıcıları uyarma amacı ile yapıldığı bulunmuştur. Toplam şikâyet sayısı 346 olmasına rağmen, kullanıcıların karşılaştıkları problemleri dile getirmelerinde birden fazla amaç olduğu gözlenmiştir. Özellikle şikâyetini dile getiren katılımcıların aynı zamanda diğer biletix müşterilerini uyardığı gözlenmiştir. 
Tablo 2: Kullanıcıların Şikâyet Amacı

\begin{tabular}{|l|c|c|}
\hline Şikâyetin Yapılma Amacı & (f) & (\%) \\
\hline Şikâyeti dile getirme (SDG) & 137 & 33,74 \\
\hline Başkalarını uyarma (BU) & 126 & 31,04 \\
\hline Çözüm bekleme (ÇB) & 143 & 35,22 \\
\hline Toplam & $\mathbf{4 0 6}$ & $\mathbf{1 0 0}$ \\
\hline
\end{tabular}

Biletix kullanıcılarının şikâyet amaçları ile ilgili şikâyet metinlerinden birer örnek aşağıda verilmiştir.

SDG: Biletix'ten bilet aldık en arka sırayı vermiş. Bir de arkadaşlar fazla ücret alıyor iyi yerden stra tahsisi yapılacak diye. Uygun yer bir tek orası kalmış. Bizden sonra bilet alanlar ön koltuktan almış. Bu şekildeki ilkel işlemleriniz için sizi kınıyorum. Bir daha da sizin siteden iğne almam.

BU: “... satış bayiinden almak isterseniz $7 \mathrm{TL}$, kargo ile gönderilmesini isterseniz 10 TL ödüyorsunuz. Evet, yanlı̧̧ okumadınız, internetten satın aldığınız biletleri gidip kendiniz aldığınızda da para ödemeniz gerekiyor..."

ÇB: Sitenizden bir tam bir öğrenci bileti aynı anda alamıyorum. Ayrı bir şekilde almaya kalksam iki kere hizmet bedeli ödemek zorunda kalacağım. Konu ile ilgili yardımol olmaları için müşteri hizmetlerini yaklaşık 2 gündür arıyorum ve daha kimse ile görüşemedim hep sıradasını deniyor. Twitter üzerinden yazdım, info maillerine mail attım, Instagram'dan yazdım daha kimse geri dönmedi. Acil konu ile ilgili geri dönüşünüzü bekliyorum.

\section{Şikâyet Kategorilerinin Belirlenmesi}

\section{Şikâyet Ana Temaları}

Ana temalar belirlenirken şikâyetler tek tek okunarak kendi içerisinde ana temalarına göre ayırılmıştır. Şikayetvar.com sitesinde bulunan şikâyetlerin ana temaları ve alt temaları Tablo-3'te gösterilmektedir.

Tablo-3: Ana Şikâyet Temaları

\begin{tabular}{|c|c|c|}
\hline Şikâyet Ana Tema & (f) & $(\%)$ \\
\hline Hizmet & 105 & 24,4 \\
\hline Fiyat & 105 & 24,4 \\
\hline Müşteri hizmetleri & 58 & 13,5 \\
\hline Web & 42 & 9,7 \\
\hline Mekân & 45 & 10,4 \\
\hline Bilgilendirme & 34 & 7,9 \\
\hline Dağıtım & 28 & 6,5 \\
\hline Promosyon & 12 & 2,7 \\
\hline Toplam & 429 & 100 \\
\hline
\end{tabular}

Biletix web sitesinden etkinlik alanların şikâyetlerinin ana temaları sekiz başlık halinde ortaya çıkmıştır. Bu ana temalar; hizmet, fiyat, web sitesi, müşteri hizmetleri, dağıtım, promosyon, fiyat ve bilgilendirme konusundaki şikayetlerdir. Her ana temanın altında ise alt temalar 
oluşturulmuştur. Toplamda ana tema şikâyet sayısı $429^{\prime}$ dur. Hizmet ve fiyat ile ilgili şikâyetler $\% 24,4$ ile en yüksek şikâyet alan ana temalardır. Bunları \%13,5 ile müşteri hizmetleri, \%10,4 ile mekân takip etmektedir.

\section{Şikâyet Ana Temalarının Alt Temaları}

Her ana şikâyet tema ayrı dosyalar halinde ayrılmıştır. Ayrılan her ana tema dosyasında yer alan şikâyetler okunarak alt temalar oluşturulmuştur. Ana tema oluşturmada olduğu gibi her şikâyet konusu birbirinden farklı ana ve alt tema altında yer alabilmiştir. Bu doğrultuda oluşturulan alt temaların toplam sayısı 795 adettir. Şikâyet temaları ve alt temaları Tablo-4'te gösterilmektedir.

Hizmet: Biletix'in sunmuş olduğu bilet satma işlemi ile ilgili kullanıcıların yaşadıkları aksaklıklarla ilgili dile getirilen şikâyetler hizmet başlığı altında değerlendirilmiştir. Toplam şikâyet içerisinde hizmet şikâyetlerinin toplamı 105 adettir. Hizmet teması altında toplanan şikâyetler sekiz alt tema altında toplanmıştır. Alt temalar oluşturulurken bazı şikâyetler birden fazla şikâyet alt teması altında değerlendirildiğinden dolayı 167 şikâyet sayısına ulaşmıştır. Bu alt temaların büyük çoğunluğu yapılan işlem sonucunda iade işlemlerinin yapılamaması ile ilgilidir.

İade edilemeyen bilet, para iadesinin yapılmaması toplam hizmet alt temasının \%52,20'sini oluşturmaktadır. Biletix'in ana görevi olan bilet satışı işlemini gerçekleştirme ile ilgili olarak kullanıcıların sistemden bilet alamaması ve iptal edilemeyen bilet ile ilgili şikâyetlerin oranı ise \%9,58' dir. Bu başlık altında ilginç olan bir şikâyet alt teması ücretsiz etkinlik için ücret alınması ile ilgili bir adet şikâyet bulunmaktadır.

Serdar, İstanbul, Festival... Biletix iptal edilen etkinliğ̈in bilet parasını iade etmedi. Telefonla iletişim kurdum, fakat geri dönmediler.

Makbule, Ankara, Festival... Konser için fhkvb referansh işlem ile 2 kişilik bilet satın aldım. Cermodern'e geldiğimizde ise çalışanlar biletimizi şaşkınlıkla karşıladı. Etkinliğin biletsiz ve ücretsiz olduğunu, bilete gerek olmadığın ifade ettiler. Ücretsiz bir etkinlik için bilet satıp ilgi ve iyi niyetimizi suistimal eden Biletix.com'u esefle kınıyor, bilet ücretimizin iadesi için gereğini arz ediyoruz.

Fiyat: Fiyat ile ilgili 199 şikâyetin \%92,46'sı $(70+61+53)$ bilet fiyatı ile ilgili olmayan ancak bilet fiyatına eklenen hizmet bedeli, hızlı bilet ve cepte bilet fiyatlandırma politikaları ile ilgilidir. Bu konudaki şikâyetlerin büyük çoğunluğunda ise firmanın pazarda rakibi olmamasından yani tekel piyasadan kaynaklı olduğunu kullanıcılar dile getirmektedir (\%30,7). Ayrıca kullanıcıların bilet teslim fiyat uygulamalarında toplu bilet alımı için bu bedellerde farklılaşma olmaması ve her bilet için ayrı ek bedeller istenmesi de önemli şikâyetler $(\% 4,1)$ içerisinde değerlendirilmektedir.

Kuddusi, İstanbul, Rekreasyon PDF bilet için ekstradan 3.5 TL almanız gerçekten kandırmadan başka bir şey değil. Zaten hizmet bedeli alıyorsun. PDF ve QR'dan da para almak nedir Allah aşkına?

Mine, İstanbul, Rekreasyon Mail ile gönderilen bilet bedeli için 3.5 TL teslimat bedeli almak nasıl bir mantıktır? Developer tek tek mi mail atıyor, herkes için mesai mi harcıyor? Bir tek sizden alabiliyoruz biletleri bunun tekel olduğunuz için mi alıyorsunuz bu ücreti? 
Tablo-4: Şikâyet Ana Temaları ve Alt Temaları

\begin{tabular}{|c|c|c|c|c|c|c|c|}
\hline $\begin{array}{c}\text { Ana } \\
\text { Tema }\end{array}$ & Alt Tema & $\mathbf{N}$ & $\%$ & $\begin{array}{c}\text { Ana } \\
\text { Tema }\end{array}$ & Alt Tema & $\mathbf{N}$ & $\%$ \\
\hline \multirow{9}{*}{ 密 } & İade edilemeyen bilet & 52 & 31,2 & \multirow{7}{*}{ 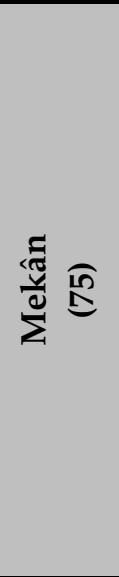 } & $\begin{array}{l}\text { Yanlış/değiştirilen koltuk } \\
\text { numarası }\end{array}$ & 27 & 36,0 \\
\hline & Para iadesinin yapılmaması & 35 & 20,9 & & $\begin{array}{l}\text { Birden fazla bireye satılan } \\
\text { koltuk }\end{array}$ & 14 & 18,6 \\
\hline & Bilet gün değişikliği & 18 & 10,7 & & Mekâna girememe & 1 & 1,3 \\
\hline & Kayıp unutulan bilet & 8 & 4,8 & & $\begin{array}{l}\text { Vip bileti ile vipten } \\
\text { girememe }\end{array}$ & 7 & 9,3 \\
\hline & İptal edilemeyen bilet & 16 & 9,6 & & Mekânın uygun olmaması & 12 & 16,0 \\
\hline & $\begin{array}{l}\text { Kesilmeyen/maille bilet } \\
\text { gelmemesi }\end{array}$ & 12 & 7,2 & & $\begin{array}{l}\text { Mekân personeli (kara } \\
\text { borsa, kaba davranış, bahşiş } \\
\text { isteme) }\end{array}$ & 11 & 14,7 \\
\hline & Bilet alamama & 16 & 9,6 & & Kalabalık & 3 & 4,1 \\
\hline & $\begin{array}{l}\text { Etkinlikten memnun } \\
\text { olmama }\end{array}$ & 7 & 4,2 & \multirow{4}{*}{ 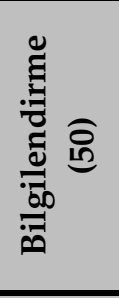 } & Yaş sınırı & 15 & 30,0 \\
\hline & $\begin{array}{l}\text { Diğer (sahte bilet, ücretsiz } \\
\text { etkinliğe ücret) }\end{array}$ & 3 & 1,8 & & İptal olan etkinlik & 21 & 42,0 \\
\hline \multirow{6}{*}{ 蛋 } & Fiyat artış1 & 3 & 1,5 & & Etkinlik tarih değişikliği & 2 & 4,0 \\
\hline & Hizmet bedeli & 70 & 35,2 & & Etkinlik başlama saati & 12 & 24,0 \\
\hline & Hizlı bilet & 61 & 30,7 & \multirow{7}{*}{ 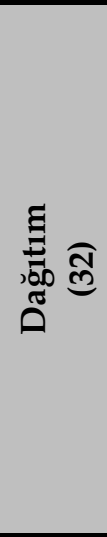 } & Kurye teslim ek bedel & 15 & 46,8 \\
\hline & Cepte bilet & 53 & 26,5 & & Yanlış adrese bilet teslimi & 2 & 6,2 \\
\hline & $\begin{array}{l}\text { Topluca alınan biletlerde } \\
\text { ayrı ayrı hizmet bedeli }\end{array}$ & 8 & 4,1 & & $\begin{array}{l}\text { Biletix şube personeli kaba } \\
\text { davranış }\end{array}$ & 1 & 3,1 \\
\hline & Tekelleşme & 61 & 30,7 & & \begin{tabular}{|l} 
Teslimat eksikliği \\
\end{tabular} & 7 & 21,8 \\
\hline \multirow{7}{*}{ 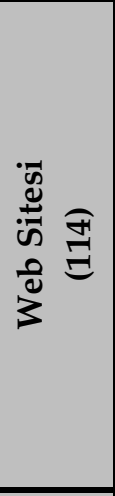 } & Onaylanmayan bilet & 13 & 11,4 & & $\begin{array}{l}\text { Hediye alınan biletin hediye } \\
\text { paketine konulmaması }\end{array}$ & 3 & 9,3 \\
\hline & Kampanyalara ulaşamama & 11 & 9,7 & & $\begin{array}{l}\text { VIP biletin alınması ama } \\
\text { VIP alanın olmaması }\end{array}$ & 2 & 6,2 \\
\hline & $\begin{array}{l}\text { Ücretin hesaptan çekilmesi } \\
\text { biletin onaylanmaması }\end{array}$ & 38 & 33,3 & & Sira bekleme & 2 & 6,2 \\
\hline & İşlem hatası & 11 & 9,7 & \multirow{3}{*}{ 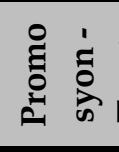 } & Yanlış kampanya bilgisi & 7 & 33,3 \\
\hline & Sistem yavaşlı̆g 1 & 31 & 27,2 & & Hediye kart kullanımı & 10 & 47,6 \\
\hline & Koltuk no seçememe & 7 & 6,1 & & İstenmeyen tanıtım Bilgisi & 4 & 19,1 \\
\hline & Üyelik işlemleri & 3 & 2,6 & & & & \\
\hline \multirow{5}{*}{ 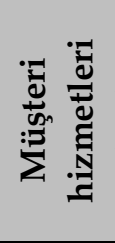 } & Ulaşamama & 47 & 34,3 & & & & \\
\hline & Kaba müşteri temsilcisi & 17 & 12,4 & & & & \\
\hline & Sorun çözememe & 41 & 29,9 & & & & \\
\hline & Uzun bekletme & 23 & 16,8 & & & & \\
\hline & Geribildirim & 9 & 6,6 & & & & \\
\hline
\end{tabular}

Web sitesi: Web sitesi ile ilgili şikâyetler toplam şikâyetlerin \%12,13'ünü (42 adet) oluşturmaktadır. Bu şikayetler online işlem sırasında kullanıcıların karşılaştıkları problemlerle ilgilidir. Web sitesi ile ilgili şikâyet metinleri alt tema oluşturulması esnasında ana şikâyet altında yedi alt tema ve 114 adet şikâyet kayıt altına alınmıştır. Web sitesi ile ilgili yaşanan en önemli 
problemin bilet alımı esnasında kullanıcının biletin onaylanmamasına rağmen banka hesabından ücretin kesilmesi alt temasıdır. Bu alt şikâyet konusu web sitesi ile ilgili şikâyetlerin \%33, 33 (38 adet) oluşturmaktadır. Sistem yavaşlığı ise \%27,19 ile ikinci sırada yer almaktadır. Bu şikâyetleri sırası ile onaylanmayan bilet, kampanyalara ulaşamama, işlem hatası, koltuk numarası seçememe ve üyelik işlemlerinin yapılamaması takip etmektedir.

Erdem, İstanbul, Maç.... Fenerbahçe Spor Kulübü Panatinakos maçına 2 bilet aldım ama sistemde hata oluştu ve biletlerin parasını çekmesine rağmen biletleri bana satmadi.

Ömer, Samsun... Biletix.com sitesine bilet almak için üyelik yapmaya çalışıyorum ama hiçbir şekilde olmuyor mobil uygulama üyeliği tamamla dediğimde uygulamadan atıyor bilgisayardan yapmaya çalıştı̆̆ımda da sayfa hata veriyor ve hiçbir şekilde üye olamiyorum.

Müş̧teri hizmetleri: Müşteri hizmetleri ile ilgili şikâyetler toplam şikâyetlerin \%16,76'sını (58 adet) oluşturmaktadır. Bu şikâyetler kullanıcıların karşılaştıkları problemlerle ilgili şikâyetlerini yetkili birine iletmek amacı ile müşteri hizmetlerine aramaları sonucunda ortaya çıkmıştır. Müşteri hizmetleri ile ilgili şikâyet metinleri alt tema oluşturulması esnasında ana şikâyet altında beş alt tema ve 137 adet şikâyet kayıt altına alınmıştır. Müşteri hizmetleri ile ilgili en çok konser etkinliği için bilet alan kullanıcılar şikâyette bulunmuşlardır. Müşteri hizmetleri ile ilgili yaşanan en önemli problemin müşteri hizmetlerine ulaşamama alt temasıdır.

Ömer, Antakya, Tiyatro Müş̧eri hizmetlerine ulaşamama: "Trump ile görüşebilme ihtimaliniz daha yüksek ya da telefonun karşısında alo deme ihtimali"

$\mathrm{Bu}$ alt şikâyet teması müşteri hizmetleri ile ilgili şikâyetlerin \%34,30'unu (47 adet) oluşturmaktadır. Sorun çözememe \%29,92 ile ikinci sırada; uzun bekleme süresi \%16,78; çağrı merkezi çalışanlarının kaba davranışı \%12,40 ve son olarak da problem yaşayan kullanıcıların problemlerini dinleyen müşteri temsilcilerinin geribildirimde bulunmaması ise $\% 6,56^{\prime}$ lık oranla son siradadır.

İrem, Ankara, Konser Biletix.com'dan aldığımız konser bileti ile ilgili soru sormak için müşteri hizmetlerini yaklaşık 5 kere arayıp 10'ar dakika bekledik, hala daha kimseye ulaşılamıyor.

Mekân: Biletix tüm ülke çapında organize edilen etkinliklerin biletini satan bir aracı kurumdur. Bu etkinliklerin gerçekleştirildiği yerlerdeki mekânın tasarımından personelin davranışına kadar geçen sürede yaşanan deneyimler Biletix'in sorumluluğunda olarak algılanmaktadır. Bu noktada kullanıcıların önerdiği nokta her etkinlik biletinin satılmaması ve organizasyonların gerçekleştirileceği mekânlarda da bir kontrol sisteminin oluşturulması yönündedir. Mekân ile ilgili ana temanın altında yanlış/değiştirilen koltuk numarasının verilmesi \%36 ile en çok şikâyet edilen mekân alt temasıdır. Bunu birden fazla bireye ayn koltuk numarasının verilmesi izlemektedir (\%18,6). Mekânın etkinliğin gerçekleştirilmesi için uygun olmadığı ile ilgili şikâyetler ise \%16'dır. Mekân personelinin bahşiş istemesi, yüksek fiyatlı bilet satması ve kaba davranması ise $\% 14,7^{\prime}$ lik bir orana sahiptir.

Murat, Ankara, Konser... Blues konseri bileti için işlem yaptığım tarihte a3-a5 koltuk numarası gözükürken, bileti almaya gittiğgimde $k 3-k 5$ koltukları verildi.

İsmail, İstanbul, Tiyatro... Görevli arkadaşlar bahşişle çalıştıklarımı söylediler. Hem biletimi kafalarına göre değiştirip üstüne üstlük bir de bahşiş talep ediyorlar.

Bilgilendirme: Biletix şikâyet konuları içerisinden biri de bilgilendirme eksikliği ile ilgilidir. Bilgilendirmenin hangi durumlarda ortaya çıtığına baktığımızda ise etkinliklere katılım 
sırasında yaş sınırı, iptal edilen etkinlik, etkinlik tarih değişikliği ve etkinlik başlama saati ile ilgili olduğu görülmektedir. Bu alt temalar içerisinde en yüksek orana iptal edilen etkinlik ile ilgili bilginin iletilmemesi \%42'lik bir orana sahiptir. Etkinlik başlama saatinin yanlış verilmesi ise \%24 oranındadır. Bu konu da dağıtım konusunda olduğu gibi etkinlik organize eden kurum ile Biletix arasındaki iletişimsizlikten ya da ani olarak etkinliklerin iptal edilmesinden dolayı Biletix firmasının da haberdar olmamasından kaynaklanmaktadır.

Furkan, Bursa, Konser.... Bursa konseri için gişeden bilet aldım. 18 yaş sınırının olmadığı sadece içerisinde 18 yaş altının alkol alamayacağı söylendi gişedeki kişinin yanlış bilgilendirmesi yüzünden 2 tane biletim elimde kaldi.

Şengül, İstanbul, Sirk... Tuzla'dan kalkıp Ataköy'e gidiyoruz sirki izlemeye ve koskocaman Sinan Erdem Spor Salonu'nun kapısında öğreniyoruz sirkin iptal olduğunu. Yazık bunun için hiçbir SMS bildirimi yok.

Dağıtım: Dağıtım ile ilgili şikâyet konularına baktığımızda özellikle web sitesi üzerinde bilet satın alan kullanıcıların biletlerini fiziksel olarak teslim almak istediklerinde ve biletin gişelerden alınması gerektiği durumlarda ortaya çıkan şikâyetler olduğu görülmektedir. Dağıtım alt teması içerisinde \%46,6'lık bir oran kurye teslimi için ek bedel istenmesi oluşturmaktadır. Bunu satın alınan biletin fiziksel olarak teslimatının yapılması istendiği durumda biletin kullanıcıya ulaşmamış olması \%21, $8^{\prime}$ lik bir oranla ikinci alt tema olarak ortaya çıkmıştır. Bunun dışında kullanıcıların özel günlerde yakınlarına hediye olarak aldığı biletlerin tesliminde hediye paketine konulmaması takip etmektedir. Diğer bir konu da web sitesinde alınan biletlerin biletix şubelerinde almak durumunda kalındığında uzun süre sıra beklemek dağıtım alt teması içerisinde değerlendirilmiştir. Biletix iş modelinin doğası gereği dağıtım ile ilgili şikâyetlerin genel şikâyetler içerisinde oranı oldukça az denilebilecek sayıdadır.

Görkem, İstanbul Konser... Biletlerin güzel bir hediye paketi içerisinde gelmesini beklerken; Biletix'in her zaman uyguladı̆̆ı yöntem olan, herkesin bildiği kırtasiyeden maksimum 25 kuruşa alınabilen basit bir zarfa konulmuş olarak geldi. Kırtasiyeden maksimum 25 kuruşa alınan bir zarfa 5 TL ücret vermiş oldum....

Hakan, Ankara, Maç (spor) ... En sonunda bütün kapılar açıldı, herkes içeri girdi. Ilk çeyrek bitmişti. Şimdi sorular şunlar: 1- 10.500 kişilik salonun en az yarısı internetten bilet almış olsa, bunun da diyelim ki yarısı biletini önceden almış olsa, kalan 2500 kusur kişiye 4 gişeyle nasıl bilet vereceksiniz? 2- Koskoca Ankara'da neden sadece 3 noktada Biletix teslim gişesi var? 3- Bana biletimi vermediniz, o zaman neden "bilet teslim ücreti" aldını??

Promosyon: Biletix firmasının etkinliklerinin tanıtımında ve promosyon kullanımı ile ilgili şikayetleri değerlendirildiğinde hediye kart kullanamama \%47,6, yanlış kampanya bilgisinin verilmesi \%33,3 ve son olarak da istenmeyen tanıtım bilgisinin gönderilmesi $\% 19,1$ oranındadır.

Derya, İstanbul, Gösteri... Biletix'te hediye kartım vardı onu da kullanmak istedim. Sistem ikisini aynı anda kullanamayacağımı söyledi ve Avea Prime şifremi de silip benden tam para çekti ve ben bunu ödeme yaptıktan sonra fark ettim.

Pınar, İstanbul, Konser... Biletix'teki bir kampanya ile 50 TL'lik Masterpass hediye çeki kazandım. Çekimi defalarca kullanmak istedim fakat online satış sitesinde çekimin kullanımına izin verilmedi.

\section{SONUÇ}

Şikâyet davranışı en genel ifadeyle tüketicilerin beklentilerinin karşılanmaması durumunda ortaya çıkan rahatsızlığın paylaşılmasıdır. Memnuniyetsizliklerini dile getirmek için internet ve 
teknolojiden faydalanan tüketiciler, bu rahatsızlıklarını ilgili işletmelerin gerek web sitelerine gerek aracı şikâyet sitelerinde paylaşmaktadırlar. Böylece şikâyet yönetim süreci internet ortamında yürütülmekte ve e-şikâyetlere çözüm bulunmaktadır. Araştırmada biletix.com sitesinden biletleme hizmeti alan tüketicilerin şikayetvar.com sitesine yaptıkları şikâyetler incelenmiştir. Bu kapsamda şikâyet metinleri okunarak temalara ayrılmıştır. Hizmet, fiyat, web sitesi, müşteri hizmetleri, mekân, bilgilendirme, dağıtım, promosyon/tanıtım şeklinde sekiz ana temaya ulaşılmıştır. En fazla şikâyetin, fiyat (199 adet) ve hizmet (167 adet) temalarında olduğu tespit edilmiştir. Hizmet ve fiyatlama, işletmelerin tüketicileri memnun etmek için en çok önem vermeleri gereken alanlardır.

Araştırma sonuçlarına göre hizmet ana teması altında yapılan şikâyetler, bilet satışı sonrasında oluşan hizmet hataları ile ilgili olmuştur. Ancak bu şikâyetlerin 7'si $(\% 4,2)$ biletix.com firmasının dışında etkinliği yürüten organizasyona yönelik memnuniyetsizlik içeren şikâyetler olmuştur. Bir diğer şikâyet ise sahte bilet şikâyetleridir. Bu şikâyet alt teması da biletix.com sitesinde belirtilen satış noktaları ve üye gişeler dışında tüketicilerin kendi kararları ile alınan biletleri ifade etmektedir. Biletix.com bu konuda tüketicileri bilgilendirmek amacıyla web sitesinde satış noktalarını belirtmektedir. Ancak, bu durumla karşılaşarak şikâyet eden tüketicilerin detaylı bilgi için web sitesindeki açıklamaları bütünsel bir şekilde okumadıkları anlaşılmaktadır. Biletix.com bu konuda tüketicileri bilet satış işlemi esnasında ön bilgilendirme ve satış sözleşme formunda maddeler halinde detaylı olarak bilgilendirmektedir.

Fiyatlama politikası en çok şikâyet konusu olan tema olarak saptanmıştır. Biletix.com, bilet ücretine ilaveten, hizmet bedeli, kurye bedeli gibi ek ücretler koyarak bilet satışını tamamlamaktadır. Ancak hem kurye hem de hizmet bedeline yönelik fiyatlama bilet fiyatı üzerinden oran hesabı yapılarak satılmaktadır. Biletix.com Türkiye'de mega etkinlikler için bilet satışı yapan tekelleşmiş bir firma olarak dilediği fiyatlama politikasını izleyebilmektedir. Bu durum biletix.com için hizmet hatası olarak değerlendirilebilir. Çünkü her biletin kurye hizmeti ve biletix.com tarafından sağlanan bilet satış hizmeti standart bir maliyet olarak görülmektedir. $\mathrm{Bu}$ yüzden kurye ve hizmet bedelinin bilet fiyatına oranla ek ücret ödenmesi tüketiciler tarafından adil olarak karşılanmamaktadır. Biletix.com işletmesi fiyat konusunda tekelci piyasa gücüne dayanarak farklı ek bedeller talep etmektedir. Bu durum aynı hizmeti verecek farklı bir işletmenin piyasada yer alması durumunda Biletix.com için kötü sonuçlar doğurabilir.

Tüm satış ve biletleme işlemlerini web sitesi üzerinden sağlayan biletix.com, web sitesi şikâyet teması altında, sistem yavaşlı̆̆ı, işlem hatası, paranın çekilip biletin onaylanmaması gibi web sitesine bağlı şikâyetler yer almıştır. Online bir dağıtım kanalı olması nedeniyle web sitesi bu tür işletmeler için çok önemlidir. Biletix.com için web sitesi işletmenin verdiği ana hizmet olarak değerlendirilmektedir. Bu tür hizmet hatalarının iyileştirilmesi ve güncel, kullanışlı, hızlı hizmet sağlayan bir web sitesi halini alması gerekmektedir. Web sitesinde çözülemeyen işlemler için tüketiciler müşteri hizmetlerinden faydalanmak isterler. Ancak biletix.com'a yönelik şikayetler, müşteri hizmetlerine ulaşamama, hat üzerinde uzun bekleme, geri bildirim sorunu ve kaba müşteri temsilcisi gibi şikayetler içermektedir. Bu durum ile ilgili olarak, biletix'in çalışanlarını eğitmesi ve hizmet süreci hakkında periyodik olarak uygulamalarla güncellemesi gerekmektedir. Ayrıca, milyonlarca etkinlik tüketicisine biletleme hizmeti sunan bir işletmenin geniş ve nitelikli bir çağrı merkezine sahip olması beklenmektedir. Dolayısıyla, müşteri hizmetlerini hem tüketicilerin şikâyetlerini dinleme hem de etkinlik süresince danışma hattı olarak kullanmayı eşgüdümsel olarak görev edinmelidir.

Biletix.com için başka bir şikâyet teması da "mekân" olarak tespit edilmiştir. Biletix'in aracı bir kurum olması nedeniyle etkinlik mekânı üzerinde bir yetkiye sahip olmadığı görülmektedir. 
Mekândaki koltuk düzeni, VIP giriş-çıkışları, mekân personeli ve kalabalık gibi temaların altında yer alan şikâyetler aslında etkinlik organizasyonuna yönelik şikâyetler olarak değerlendirilmelidir. Biletix'in biletleme hizmeti verdiği organizasyonlarda etkinlik mekânına karşı bir sorumluluğu bulunmamaktadır. Bilgilendirme teması altında da iptal edilen etkinliğin haber verilmemesine yönelik şikâyetler çoğunluktadır (\%42). Bu şikâyetler, etkinlik organizasyonu ve biletix arasındaki işbirliğinde yaşanan aksaklıklar sonucu ortaya çıkabileceği anlaşılmaktadır. Nitekim etkinlik ile ilgili değişimler öncelikle aracı kuruma sonrasında bilet sahibi tüm tüketicilere sms, e-posta ve biletix.com web sitesindeki duyurular kısmında açıklanmalıdır.

Biletix.com şikayetleri içerisinde en az sayıda şikâyet "dağıtım" (32) ve "promosyon-tanıtım" (21) olduğu saptanmıştır. Alt temalara bakıldığında, dağıtım sürecinde kuryenin yanlış adrese teslimi, VIP alanı bilgisinin yanlıs girilmesi, kurye teslimi ek bedel, hediye paketi sorunu gibi şikâyetler olduğu görülmüştür. Türkiye'nin farklı bölgelerinde yapılan bilet teslimatları için farklı sorunlar ortaya çıkabilmektedir. Bu konuda, kargo şirketlerinin Biletix ile yapacakları ikili anlaşmalar dağıtım ile ilgili sorunu çözebilecektir. Bir diğer alt temada ise, hediye kart ve istenmeyen tanıtım mesaj ve postaların gönderilmesini içeren şikâyetler yer almaktadır.

Genel olarak şikâyetler incelendiğinde, tüketicilerin kendilerine olan haksız durumlarla karşı karşıya kaldıkları ve çözüm bulamadıkları anlaşılmaktadır. Biletix işletmesi tüketicilere kaliteli ve doğru hizmet sunmak için hizmet standartları geliştirmeli ve tüm hizmet hatalarının iyileştirilmesine yönelik temel bir hizmet üretim analizi yapması gerekmektedir. Aksi halde, tüketici memnuniyetsizliği katlanarak işletmenin itibarı zedelenecektir. Bu durum, doğrudan biletix.com, dolaylı olarak da etkinlikleri düzenleyen organizatörlerin etkilenmesine sebep olabilir. Tüketiciler Biletix' in verdiği hizmetlerden dolayı etkinliğe katılmaktan vazgeçerek farklı sosyal ve kültürel rekreasyon işletmelerine yönelebilirler. Ek olarak, Biletix işletmesi hakkındaki şikâyetler, genel itibariyle çoklu hizmet hatası ve telafi edilmeme olarak saptanmıştır. Bu yüzden Biletix'in tüketici şikâyetlerine ortak çözümler üretmesi önerilmektedir.

Biletix.com, etkinlik hizmeti veren organizatörler ile etkinlik tüketicisi olan bireyler arasında bir aracı kurum niteliği taşımaktadır. Biletix.com etkinlik süresince organizatör kaynaklı oluşan şikâyetlerden sorumlu olmamaktadır. Dolayısıyla etkinlik deneyimine ilişkin şikâyetler, biletix.com işletmesinin dışında tutularak organizatörlere yapılan şikâyetler olarak değerlendirilmelidir.

Araştırma, belirli tarihler arasındaki şikâyetlerin incelenmesi ve biletix.com işletmesi ile sınırlıdır. Bir başka sınırlılık ise sadece şikâyetlerin incelenerek, şikâyetlere yönelik var olan çözümlerin analiz dışı bırakılmasıdır. İleride yapılacak çalışmalarda özellikle e-şikâyet konusunda bilet satışı yapan diğer rekreasyon ve turizm işletmeleri incelenebilir. Ayrıca, tüketicilere sunulan hizmet telafileri değerlendirilerek hizmet sonrası memnuniyet oranları ile kıyaslama yapılabilir. Uygulama odaklı ise etkinlik düzenleyen işletmelerin kendi bünyelerinde bilet satışı yapacakları farklı mobil uygulamalar geliştirmeleri ve tüm hizmet sürecinde bütüncül bir yaklaşımla genel tatmini yüksek tutmaları önerilebilir. Biletix'de dahil olmak üzere tüm bilet satış işletmelerine, satış sonrasında mesaj veya mail yoluyla kullanıcılarına ulaşmaları ve şikâyette bulunan kullanıcıların bilinçlendirilmesi şikâyet yönetimi konusunda bilgilendirilmesi önerilebilir. 


\section{KAYNAKÇA}

Alrawadieh, Z. ve Demirkol, Ş. (2015). Konaklama İşletmelerinde E-Şikâyet Yönetimi: İstanbul'daki Beş Yıldızlı Oteller Üzerinde Bir Çalışma. Nişantaşı Üniversitesi Sosyal Bilimler Dergisi 3(1), 132-151.

Aylan, S., Arpacı, Ö. ve Celiloğlu, F. K. (2016). Bir internet şikâyet forumundaki termal otellere yönelik şikâyetlerin incelenmesi. Çankırı Karatekin Üniversitesi Sosyal Bilimler Enstitüsü Dergisi, 7(1), 49-68.

Aymankuy, Y. Ş. (2011). Yerli Turistlerin İnternet Ortamındaki Şikâyetlerinin Satın alma Kararlarına Etkileri. Balikesir University Journal of Social Sciences Institute, 14(25), 218-238.

Barış, G. (2008). Kusursuz Müşteri Memnuniyeti İ̧̧in Şikâyet Yönetimi, İstanbul: Mediacat.

Beaven, Z. and Laws, C. (2004). Principles and applications in ticketing and reservations management. Festival and events management: An international arts and culture perspective, 183-201.

Bell, J. B., Menguc, B. and Stefani, S. L. (2004). When Customers Disappoint: A Model of Relational Internal Marketing and Customer Complaints. Academy of Marketing Science, 32(2): 112-126.

Bhave A. and Budish, E. (2017). Primary-Market Auctions for Event Tickets: Eliminating the Rents of 'Bob The Broker'? NBER Working Paper Series.

Biletix.com (2019). Web Sitesi Tanıtım Sayfası. Erişim Tarihi: 27.08.2019.

Bowdin, G., Allen, J., Harris, Ian McDonnell, R. and O'Toole, W. (2006). Events Management, John Wiley \& Sons, Australia.

Buhalis, D. (1998). Strategic Use of Information Technologies, in the Tourism Industry, Tourism Management, 19(5), 409-421.

Cevher, E. (2016). Hizmet Kalitesi Açısından Üniversitelere Yönelik Şikâyetlerin İncelenmesi. Journal of Yasar University, 11(43), 163-171

Creswell, J. W. (2014). A Concise Introduction to Mixed Methods Research. SAGE publications.

Doğru, H., Kaygalak, S., Miral, Çavdırlı C. ve Bahçeci, V. (2014), Engelli Bireylerin Turizm Hizmetlerine Yönelik E- Şikâyetleri, Gazi Üniversitesi Turizm Fakültesi Dergisi, 2, ss.33-47.

Erk, Ç. (2009). Müşteri İçin Değer Yaratma, Müşteri Sadakati Oluşum Süreci ve Şirket Performansina Etkileri Üzerine Araştırma. Trakya Üniversitesi, Sosyal Bilimler Enstitüsü: Edirne.

Eroğlu, A. H., Kanıbir, H., ve Eker, Ö. G. N. (2008). Endüstriyel İşletmelerin Dağıtım Kanalı Seçimini Etkileyen Faktörlerin Belirlenmesine Yönelik Bir Çalışma. Süleyman Demirel Üniversitesi İktisadi ve İdari Bilimler Fakültesi Dergisi, 13(1), 95-110.

Europe-Economics (2009). Analysis of the Secondary Sales Market for Tickets for Sporting, Cultural and Other Events - Eeurope-economics.com

Gökdeniz, İ., Bozaci, İ. ve Karakaya, E. (2011). Şikâyet Yönetim Süreci Sonrası Memnuniyeti Etkileyen Faktörler Üzerine Uygulamalı Bir Araştırma. Selçuk Üniversitesi Sosyal Bilimler Enstitüsü Dergisi, (26), 173-185.

Jennings, M. M. and Happel, S. (2002). The post-Enron era for stakeholder theory: A new look at corporate governance and the Coase theorem. Mercer L. Rev., 54, 873.

Kulabaş, Y. ve Sezgin, S. (2003). Torque-Müşteriyi Geri Döndürme Kuvveti/Bir İlişkisel Pazarlama Modeli, İstanbul Teknik Üniversitesi Dergisi, 2 (5),74-84. 
Lincoln, Y. S. and Denzin, N. K. (2003). Turning points in qualitative research: Tying knots in a handkerchief (Vol. 2). Rowman Altamira.

Lovelock, C. H. and Wright, L. (1999). Principles of Service Marketing and Management, Prentice Hall Inc., Upper Saddle River, New Jersey.

Özkaynar, K. (2010). Türkiye'de Sanal Şikâyet Uygulamalarının Algılanmasına Yönelik Bir Araştırma: Şikayetvar.com örneği. Sakarya Üniversitesi Sosyal Bilimler Enstitüsü, Yayınlanmamış Yüksek Lisans Tezi.

Pei-wu, D. and Yan-qiu, H. (2006). Research of Customer Complaints and Service Recovery Effects. Management Science and Engineering, ICMSE International Conference.

Sarı, F.Ö., Alikılıç, Ö. and Onat, F. (2013). E-Complaining: Analysis of Lodging Customers' eComplaints from a Turkish Internet Website, International Conference on Information, Business and Education Technology (ICIBIT). Beijing, China. 561-565.

Sarı, Y. ve Kozak, M. (2005). Turizm pazarlamasına internetin etkisi: Destinasyon web siteleri için bir model önerisi. Akdeniz Iİ BF Dergisi, 9, 248-271.

Singh, J. and Widing, R. (1991). What Occurs Once Consumers Complaint? A Theoretical Model for Understanding Satisfaction/Dissatisfaction Outcomes of Complaint Responses, European Journal of Marketing, 25 (5), 30-46.

Şahin, F. ve Alkaya, A. (2017). Tüketicilerin Çevrimiçi Şikâyet Kanallarını Kullanımına Yönelik Davranışlarının: Teknoloji Kabul Modeli ve Planlı Davranış Teorisi Bütünleşik Modeli Bakış Açısı ile İncelenmesi. PESA Uluslararası Sosyal Araştırmalar Dergisi, 3(4), 87-103.

Tokay Argan, M. ve Yüncü, D. (2016). Etkinlik Pazarlama Yönetimi, Detay Yayıncılık.

Tokay Argan, M. ve Arıcı, A. (2019). Sağlık İletişiminde E-Şikâyet: Hastaların ve Hasta Yakınlarının Sikayetvar.com Paylaşımları Üzerine Bir Araştırma. Akdeniz Üniversitesi İletişim Fakültesi Dergisi, (31), 339-355.

Ünver, C. (2010). Müşteri İlişkileri Yönetimi: Müşteri Şikâyetleri ve İnternet, Sosyal Bilimler Enstitüsü Halkla İlişkiler ve Tanıtım Anabilim Dalı, Yayınlanmamış Yüksek Lisans Tezi, Ankara.

Vos J.F.J. and Huitema, G.B. (2008). How Organizations Can Learn from Complaints, The TQM Journal, 20(1), 8-17.

Yıldırım, N. T. (2015). Fiyatlandırma ve İnternet Ortamında Fiyatlandırma Stratejileri. Dicle Üniversitesi Iktisadi ve İdari Bilimler Fakültesi Dergisi, 5(8), 10-29. 